\title{
The Hanging Foliage of certain Tropical Trees.
}

\author{
BY \\ F. W. KEEBLE, B.A., \\ Frank Smart Student, Gonville and Caius College, Cambridge.
}

\section{With Plate IV.}

$\mathrm{T}$ HE habit whereby the young leaves and branches of certain tropical trees hang vertically downward during the early stages of their existence has been frequently described in recent years ${ }^{1}$.

The trees thus characterized belong, with but one exception so far as I have been able to ascertain, to the group Caesalpinieae of the order Leguminosae. Such are Amherstia nobilis, various species of Brownea (e.g. B. grandiceps, $B$. coccinea, B. hybrida), Humboldtia laurifolia, Saraca indica, and S. declinata, Maniltoa gemmipara, Cynometra cauliflora and Calophyllum bracteatum (Guttiferae). The last-named is a rare plant peculiar to Ceylon, and no opportunity of specially examining it occurred to me.

The three first-named trees, Amherstia nobilis, species of Brownea, and Humboldtia laurifolia, are those on which experiments and observations were made.

${ }^{1}$ Cf. Figs. I and 2.

[Annals of Botany, Vol. IX. No. XXXIII. March, I895.] 
Treub has well described the appearance which the young branches of such trees present: 'Very young branches, with their not yet green leaves, hang flaccidly down as though they were fallen out of the bud ${ }^{1}$.' Haberlandt, in a recent book of travel, describes them as looking as though 'poured out' of the bud ${ }^{2}$.

Treub ${ }^{3}$ and others have observed how rapidly the elongation of the shoots takes place. The following instance observed by me illustrates this. An unopened bud of Brownea grandiceps was ten inches long at six p.m. The next morning at seven o'clock the bud had opened and the petioles of the pinnate leaves which had issued from it were each a foot and a half in length. During the next two days they grew at the rate of little less than a foot a day, and had at the end of that time practically attained their full length.

During this elongation the leaflets are rolled longitudinally on themselves with their upper surface inwards. Similarly in Amherstia nobilis, during the short period of elongation, the very small, tender, hanging leaflets are folded on themselves along their midrib so as to include the upper surfaces. At first sight it might be imagined that this folding and rolling are devices for protection of the upper surfaces; but when the transientness of this condition is remembered, and especially the great rate at which the leaflets have been separated by the elongating petiole, it seems more likely that the folding or rolling is rather to be explained by the ordinary laws of vernation than of special adaptation. In a few days the still hanging leaflets of Brownea grandiceps unroll, those of Amherstic nobilis unfold; these latter assume a bright red colour by the formation of rosy cell sap; those of the former pass from a pink flecked with white to a greener hue.

Several distinct views as to the significance of the hanging

1 Treub, M., Jets over Knoppbedekking in die Tropen; Bot. Centralblatt, Vol. xxxv, p. 329 .

${ }^{2}$ Haberlandt, G., Eine botanische Tropenreise, p. II 7 .

Treub, loc. cit. 
habit have been put forward by various investigators. Potter, in a paper on bud-protection in the tropics ${ }^{1}$, points out that the young leaves, by virtue of their disposition in a vertical plane, escape much of the damaging effect which the powerful perpendicular rays of a tropical sun might produce. In Amherstia nobilis, moreover, each pair of leaflets overlaps to a large extent the pair below, so that the surface exposed directly to light is still further reduced. Similarly also, in species of Brownea, the massing together of the several branches arising from a bud affords a considerable amount of mutual covering and, if need be, protection to the leaves. Potter, assuming that the extremely thin and delicate young foliage needs normally a protection against the powerful chemical or thermal action of the sun's rays, suggests that protection is afforded by the disposition of all the leaves in a vertical plane.

A fuller discussion of this view will be entered into later; it may, however, here be observed that the young secondary petioles are so flaccid that the leaflets borne by them hang vertically downward, no matter in what position the branch or the main petiole may be held; so that the hanging of the branch would, on this view, seem superfluous. It is true that later these secondary petioles become more rigid; but in the meantime the leaflets have become tougher and presumably therefore more capable of resisting any ill effects of exposure to direct sunlight. Treub, in a paper already quoted, seems also to see a means of protection in the pendent position. The rapid growth in length of the young branch and of the petioles of its leaves, has been already referred to; but the physiological interest seems rather to centre in the check to this longitudinal growth-in the fact that several weeks after rapid growth in length has ceased it begins again. First the branch raises itself up; then the petiole of the pinnate leaf is lifted up by means of a ventral pulvinar-like swelling (polster) at its point of attach- 
ment with the branch; then the leaves also, in a way to be described, take on a generally more horizontal position.

Growth within the tropics is often so rapid-so too in these trees is the elongation of the parts of the shootthat most observers agree in ascribing to this 'waiting stage' some important biological significance.

Stahl, who has most recently examined these hanging branches, takes this view ${ }^{1}$. He, however, rejects Potter's suggestion and sees in the phenomenon a means of protection of the young leaves from the force of rain. He points out that, within the tropics, the rainfall is often far heavier and more violent than in temperate zones, and that rain in the tropics generally falls vertically, owing to the stillness of the atmosphere.

To ascertain whether the young foliage needs the protection from the sun's rays which the pendent position affords, Stahl conducted the following experiments: young leaves of Mangifera foetida, Humboldtia laurifolia, and Brownea hybrida were laid on moist blotting-paper with their stalks in water, and exposed for four and a half hours (from seven till half-past eleven) to the direct rays of the sun (at Buitenzorg). At the end of that time the leaves remained fresh and gave no indication of any destruction of chlorophyll ${ }^{2}$.

Stahl next sought to determine whether the vertically downward position afforded the young leaves any protection against too great transpiration. He found that, under similar conditions of insolation, the fully developed leaves, which had arrived at their ultimate position, dried more quickly than the young hanging leaves (Amherstia nobilis and Brownea coccinea). He observes that the mature leaves obviously require no special protection against too great transpiration; still less, therefore, do the young leaves, if they wither less readily, require any protection.

These conclusions seemed to me surprising, since, from

${ }^{1}$ E. Stahl, Regenfall und Blattgestalt; Ann. du Jard. Bot. de Buitenzorg, Tome XI. p. 146 et seq.

${ }^{2}$ Stahl, loc. cit., p. ${ }_{4} 8$. 
the older observations of Pringsheim and Wiesner ${ }^{1}$, it is known that intense sunlight does, in many cases, cause considerable destruction of chlorophyll within the leaf. More recently also, Johow ${ }^{2}$ thus sums up this view: "The more likely view as to the destruction of chlorophyll by light is that it acts indirectly .... and on this it is clear why destruction occurs more readily in shade-loving plants than in typical sun-plants and in young not fully green organs.'

I shall bring evidence to show that these trees, Brownea species, \&c., are shade-loving trees. Accepting this for the moment, it will be seen that the young leaves of such trees, since they remain tender so long, are just those which might, unless specially protected, be expected to suffer from exposure to intense sunlight.

To test Stahl's results I took a branch bearing young red foliage from a tree of Amherstia nobilis. The branch was cut under water and its cut end kept in water during the experiment. It was so adjusted that the leaflets of one side of one of the large pinnate leaves hung vertically downward, those of the other were held each in a horizontal plane. These horizontally disposed leaflets lay on moist blotting paper, and were kept flat by means of bulldog clips. After five to six hours, pieces, each $50 \mathrm{sq} . \mathrm{cm}$., were cut from an equal number of leaflets of the two sets. These were extracted in a mortar with similar quantities of alcohol, and when the extraction was complete the green colour of the two alcoholic solutions of chlorophyll was compared. That from the leaflets horizontally placed was distinctly of a lighter green than that from those which hung vertically.

The experiment was repeated with a similar result. So that these results point to a conclusion opposite to that at which Stahl arrives; for it must be inferred from the

${ }^{1}$ Wiesner, Die natürlichen Einrichtungen zum Schutze des Chlorophylls der lebenden Pflanze; Wien, 1876.

2 Johow, Ueber die Beziehungen einiger Eigenschaften der Laubblätter zu den Standortsverhältnissen ; Pringsheim's Jahrb. der wiss. Bot., Vol. xv, p. 285. 
above experiments that thin delicate leaves of Amherstia nobilis, in which the chlorophyll-grains are developing, are, when exposed for a long time to the direct rays of the sun, in danger of injury to their green colouring-matter. Therefore, whether or not the hanging position is to be regarded as being a direct adaptation to protect the leaves from such injury, this vertical position, at least incidentally, ensures that such injury is reduced to a minimum.

The second of the conclusions drawn by Stahl was next considered. This was, as already stated, that the hanging position does not signify a need for protection against excessive transpiration, since, of leaves exposed to similar conditions of insolation, he finds that the young and tender wither less readily than the tough mature leaves.

On first testing this, by means of branches of Amherstia nobilis cut under water and suspended with their cut ends under water, results similar to Stahl's were obtained. The older leaves withered sooner. On repeating the experiment, however, it was found that, after a time, the young leaves had withered to such an extent that their leaflets were rolled up longitudinally and quite faded, whereas those of the green mature leaves were still perfectly fresh. The experiment was repeated. On this occasion one of the two branches cut at the same time bore large red leaves, the other red-brown and therefore older leaves. After some hours the younger leaves were quite withered, the older ones, on the other branch, were still fresh. In the above instances the stems were kept in water. In a third case the cut ends of the stems were not kept under water. Under these still more abnormal conditions the younger leafed branch again withered more rapidly than the older.

In yet another case, two petioles, each bearing two leaflets, were put in the sun; the leaflets of one were bright green, those of the other red-brown and consequently less mature. Other two similar sets, cut at the same time, were protected from the sun. After several hours, the young red-brown leaflets, which had been exposed to the sun, were found to be 
withered, the green ones similarly placed were not; nor were either of the two shaded sets of leaflets.

Indeed the experiments were repeated so frequently as to leave no doubt that, under similar conditions of exposure, the thin delicate immature leaves of Amherstia nobilis wither more rapidly than the more fully developed leaves; that, as would perhaps be surmised, with increasing toughness and thickness there occurs an increase of resistance to too great a loss of water-together, may be, with increased facility in obtaining water; that under unfavourable conditions the younger leaves are more readily damaged than the older. Since the young leaves of Amherstia nobilis are readily injured by exposure to direct sunlight, at all events under the conditions of the above experiments, the opposite conclusion to that at which Stahl arrives might be urged-viz. that such risk of injury indicates a need, on the part of the tender foliage, of special protection, and that the hanging position is an adaptation to this end.

It does not, however, follow that the habit under examination was developed solely as such a means of protection. It is possible at least to suppose that this habit has some other, or, at all events, additional significance. It seemed worth while to compare the rates of transpiration of the mature and immature leaves.

The comparison of the rates of transpiration was generally made by aid of the potometer ${ }^{1}$. By this method is measured, not the rate of transpiration, but the rapidity with which water is taken up by the branch.

Branches were cut at $9.30 \mathrm{a} . \mathrm{m}$. and brought to the apparatus. The following numbers give the time in seconds that bubbles took in passing from one mark to the other on the capillary tube of the potometer, the bubbles being made to follow one another as rapidly as possible.

${ }_{1}^{1}$ Darwin and Phillips, Cambridge Philosoph. Soc., Vol. v, I 886. 
Branch bearing bright green leaves, Amherstia nobilis.

$\begin{array}{crrrrr} & \text { I0 } & 5 & 8 & 5 & 6 \\ & 5 & 5 & 6 & 6 & 5 \\ 5 & 5 & 6 & 7 & 7 \\ 5 & 5 & 5 & 6 & 6 \\ \text { I0 } & 6 & 5 & 6 & 6 \\ \text { I0 } & 5 & 5 & 6 & 6 \\ 5 & 5 & 6 & 6 & 6 \\ 5 & 6 & 6 & 6 & 6 \\ 5 & 6 & 5 & 7 & 6 \\ & 5 & 5 & 6 & 7 & 6 \\ \begin{array}{c}\text { Time in seconds of ascent } \\ \text { of ten bubbles }\end{array} & \frac{-}{65} & \frac{53}{58} & \frac{-}{62} & \frac{60}{60}\end{array}$

Average time of ascent of 10 bubbles $=59$ seconds.

Branch bearing red hanging foliage, Amherstia nobilis.

\begin{tabular}{|c|c|c|c|c|c|}
\hline & I0 & 10 & I0 & IO & IO \\
\hline , & IO & IO & I I & 8 & IO \\
\hline & I I & I I & I I & 9 & I I \\
\hline & 10 & 10 & I I & I I & I I \\
\hline & 13 & I0 & I 2 & 9 & 9 \\
\hline & I 2 & IO & IO & 9 & I I \\
\hline & 12 & 10 & 8 & IO & IC \\
\hline & 9 & 9 & IO & I I & 9 \\
\hline$\therefore$ & 9 & I I & IO & I I & 10 \\
\hline & I I & I I & 9 & IO & I I \\
\hline $\left.\begin{array}{c}\text { Time in seconds of ascent } \\
\text { of ten bubbles }\end{array}\right\}$ & $\overline{107}$ & $\overline{102}$ & $\overline{\mathrm{IO} 2}$ & $\overline{98}$ & 102 \\
\hline
\end{tabular}

Average time of ascent of 10 bubbles $=102$ seconds.

Now the number of leaflets on the older branch was ten, on the younger twenty-four; and measurement of surface (by tracing the outlines of the leaflets on thin paper, cutting out these shapes, and weighing), gave the surface of the young leaves equal to twice that of the older. Therefore in this instance the rates of transpiration of equal surfaces of young and old leaves are as I:4-i.e. the older leaves transpire, roughly speaking, four times as rapidly as the younger hanging leaves.

Another example of a similar experiment may be given. Three branches of Amherstia nobilis, of course from the same tree, were taken. On one, the leaves were thin, young, bright red; on another, older, as evidenced by their brownred colour; on the third, bright green. 
The numbers given below were obtained as in the preceding experiment, and represent the average rate in seconds of the passage of ten bubbles between the two marks.

In this case each branch bore ten leaflets and the total areas of the three sets of leaves differed but little from one another.

Average rate of passage of ten bubbles :

Green. Brown-green. Red.

I 23 secs. 165 secs. 204 secs.

Here also, therefore, the green leaves transpire more rapidly than the younger red-brown, and both more quickly than the youngest red leaves.

In yet a third case two branches, one of green leaves, the other of red-brown, were used. The following are the results :

Young green leaves (secondary petioles still flexible) ten leaflets, Amherstia nobilis.

\begin{tabular}{|c|c|c|c|}
\hline . & $\begin{array}{l}6 \\
6 \\
7 \\
5 \\
5 \\
5 \\
5 \\
5 \\
5 \\
5\end{array}$ & $\begin{array}{l}5 \\
5 \\
5 \\
5 \\
5 \\
4 \\
4 \\
4 \\
5 \\
5\end{array}$ & $\begin{array}{l}4 \\
4 \\
4 \\
5 \\
5 \\
4 \\
4 \\
4 \\
3 \\
3\end{array}$ \\
\hline $\left.\begin{array}{c}\text { Time in seconds of passage of } \\
\text { air bubble between marks }\end{array}\right\}$ & & $\overline{47}$ & $\overline{40}$ \\
\hline
\end{tabular}

Average time in seconds for passage of 10 bubbles $=48$.

Red-brown leaves, twelve leaflets. (Since this experiment was used also for another purpose to be mentioned directly, no less than 140 readings were taken.) The times in seconds per ten bubbles' passage are in order: $17 \mathrm{I}, 145,135,138, \mathrm{I} 38$, I $24, \mathrm{I} 37, \mathrm{I} 50, \mathrm{I} 23, \mathrm{I} 29, \mathrm{I} 3 \mathrm{I}, \mathrm{I} 36, \mathrm{I} 29, \mathrm{I} 36$. The average of these fourteen numbers is the average time of passage of Io bubbles $=\mathrm{I} 3$.

Now the weight of thin paper cut into the shapes of the ten green leaflets was $2.3 \mathrm{~g}$.; that of similar paper cut in the 
shape of the twelve red-brown leaflets was $2.045 \mathrm{~g}$.; therefore the relative areas were

$$
\frac{\text { green leaves }}{\text { red leaves }}=\frac{2 \cdot 3}{2 \cdot 045}
$$

Hence the rates of transpiration of equal surfaces :

$$
\frac{\text { green }}{\text { red-brown }}=\frac{130}{\frac{48 \times 2 \cdot 3}{2 \cdot 045}}=\frac{130}{54}
$$

So that the green leaves transpire more than twice as rapidly as the red-brown. In order to test the reliability of this potometer-method, the results obtained by it were checked by the ordinary method of weighing at intervals the branches under comparison. Thus, in the case just quoted, it was found by the potometer that the relative rates at which the young red-brown leaves and the older green leaves took up water were as I $30: 54$. Their petioleswere removed from the potometer, and were again cut under water, so that each now bore six leaflets. These petioles were fitted by means of halved corks into tubes containing water and weighed. They were weighed again after half an hour. The weighings showed the relative loss of water in the green leaf and red-brown leaf respectively to be as $3: \mathrm{I}$. Conceding that the relative areas of these two sets of six leaflets differ but little from those of the two sets of ten leaflets which the petioles originally bore, the relative areas of the two sets (vide supra) are as $2 \cdot 3$ green : $2.045 \mathrm{red}$. Hence by the weighing method the relative losses of water by equal surfaces of red-brown and green leaves =

$$
\frac{\text { red-brown }}{\text { green }}=\frac{1}{\frac{3}{2 \cdot 3} \times 2 \cdot 045}=\frac{I}{2 \cdot 66}=\frac{54}{144}
$$

and this agrees sufficiently well with $\frac{54}{130}$ obtained by the potometer.

Since, then, the older, fully-grown leaves of Amherstia nobilis transpire much more rapidly than the young hanging red leaves - and yet these latter show, by withering, ill effects 
from exposure to the sun so much more readily than the former-it must be inferred that the tougher, more leathery, mature leaves can bear with impunity a loss of water far greater than that which suffices to damage the thin, delicate immature leaves.

The next step was to determine how far this relative lowness of transpiration on the part of the red leaves was due to their mutual overlapping and vertical downward position.

The results given below show a difference-not however so marked as might be expected-between the rates of transpiration of the leaflets in the hanging overlapping (natural) position and when outspread.

The smallness of the difference is probably to be explained by the fact that the experiment was made in a very moist atmosphere and in a room out of direct sunlight.

The experiment was made by taking a healthy hanging branch of Amherstia nobilis, bearing a large pinnate leaf with red tender leaflets, and measuring the rate of transpiration, first, whilst the branch and the leaf hung vertically downward, and then when each leaflet was outspread in various convenient positions. The leaflets were spread out by means of papers folded over stretched strings appropriately placed and gummed to the extremities of the long leaf-tips.

The following are the results :

Branch held obliquely up, but the leaf and leaflets allowed to hang and overlap.

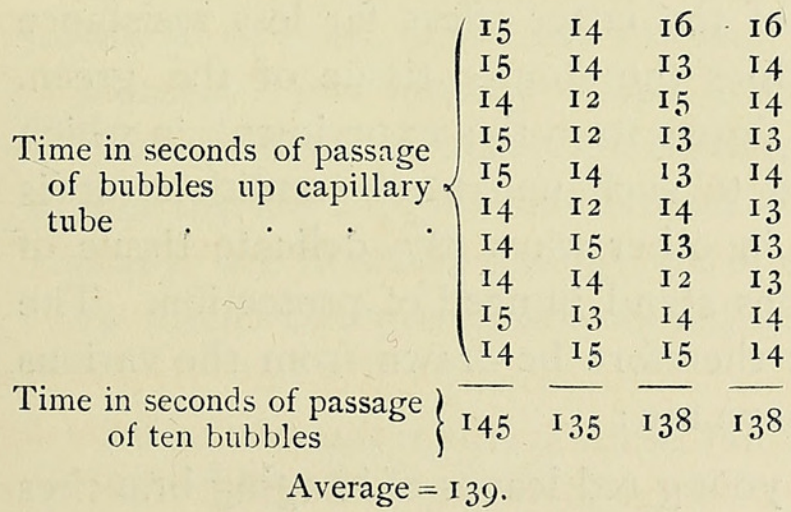

Leaflets spread out in various planes no longer overlapping.

\begin{tabular}{ll} 
I 2 & I4 \\
I2 & I 4 \\
I 2 & I4 \\
I3 & I 3 \\
I3 & I3 \\
I3 & I 4 \\
I2 & I4 \\
I2 & I3 \\
I3 & I4 \\
I3 & I4 \\
\hline I & I37
\end{tabular}

Average $=I 30 \cdot 5$. 
Leaf and leaflets allowed to hang downward, overlapping.

\begin{tabular}{l} 
I4 \\
I5 \\
I5 \\
I5 \\
I6 \\
I 5 \\
I5 \\
I 5 \\
I 5 \\
I5 \\
\hline \\
\hline
\end{tabular}

Average $=I_{5}$.
Leaflets again spread out in various planes.

\begin{tabular}{ll} 
IO & I 3 \\
I I & 14 \\
I 2 & 13 \\
I2 & I3 \\
I2 & I3 \\
I 3 & I 2 \\
I3 & I3 \\
I3 & I3 \\
I3 & I2 \\
I 4 & I3 \\
\hline I23 & I29
\end{tabular}

Average $=\mathrm{I} 26$.
Leaflets again allowed to hang vertically downward.

\begin{tabular}{ll} 
I4 & I 5 \\
I3 & I4 \\
I3 & I 4 \\
I4 & I3 \\
I3 & I3 \\
I4 & I 4 \\
I3 & I 4 \\
I 2 & I3 \\
I3 & I 4 \\
I2 & I 2 \\
\hline I3I & I36
\end{tabular}

Average $=\mathbf{I} 33 \cdot 5$.

Transpiration, then, is increased when the leaflets are spread out in various planes; so that, bearing in mind the reasons given previously for the small differences in these numbers, it may be said that the young hanging leaves of such trees as Amherstia nobilis do gain, by virtue of their position, some protection from the tax of excessive transpiration.

Before, however, drawing definite inferences from any of these experiments, it was determined to test Stahl's conclusions in yet another way. Pairs of leaflets, one young red and one older green, were cut off from leaves whose rates of transpiration had been determined. These pairs were weighed and then exposed to the sun. It was found repeatedly in such cases that the red leaflets lost weight quicker than the green, and withered sooner: that is to say, the supply of water being cut off from the leaves, green and red alike, the thin texture of the latter offers far less resistance to loss of water than does the stouter tissue of the green. If an inference may be drawn from this experiment, in which the leaves are subjected to such unnatural conditions, it is that, as already shown in other ways, the delicate tissue of the young red leaves does stand in need of protection. The conclusions which must therefore be drawn from the various experiments detailed above are :

(I) The fact that the young red leaves of hanging branches 
of Amherstia nobilis wither when in water quicker than the green leaves of lifted or partially uplifted branches, shows at least that a protection against excessive transpiration is by no means superfluous.

(2) The fact that the young red leaves of this plant transpire more rapidly when outspread than when hanging vertically, indicates that the hanging habit, whether specially adapted to that end or not, affords some measure of protection.

Of the trees which have hanging branches, not a few possess brightly coloured young foliage.

Reference has been repeatedly made to the red tint of the young leaves of Amherstia nobilis. Stahl, in addition to this instance, mentions the following: One variety of Cynometra cauliflora-bright rose-colour; Fonesia reclinata-goldengreen to bright red; Browenea hybrida and Brownea grandiceps-bright red, freckled with green. To these may be added Saraca indica-rose-coloured.

On the other hand, the young leaves borne on hanging branches are white in the following: one variety of Cynometra cauliflora, Cynometra ramiflora, Humboldtia lauriflora (except two small rosy nectaries), Calophyllum bracteatum ${ }^{1}$. Although, then, the occurrence of coloured sap is not universal among these trees, it seemed nevertheless not unlikely that, in those cases in which it occurs, it might serve as a means of protection against too strong action, either thermal or chemical or both, of the sun's rays.

Wiesner ${ }^{2}$ has already called attention to the possibility of such protection being afforded by coloured saps. Stahl makes the not insignificant remark that the leaves of Fonesia reclinata are in shade gold-green, in sun bright red ${ }^{3}$.

A direct change in leaf-colouration was observed by me

1 Trimen, Handbook of Flora of Ceylon, Part I, p. IO2; Part II, pp. I I3, I I4. 2 Loc. cit. 
in a seedling Brozenea grandiceps. The plant was raised in the diffuse light of a room, and when its leaves had assumed a good green colour it was placed in the open, exposed directly to the sun. The leaves acquired a distinct red tinge, so that probably, in response to the changed conditions of insolation, a new formation of coloured sap took place. Since writing the above I find in Johow's paper already cited ${ }^{1}$ the following statement, which seems to show to what an extent the amount of red colour in such leaves as these is the result of exposure to sun: "That the appearance of red colour in the leaf is determined by light is shown by the fact that in cases where the different leaves are differently illuminated' (referring to Brownea and Acacia species) 'those leaves most exposed to the light possess an intense red colour, those more shaded a fainter red or even bright green.'

It was sought to determine by a simple experiment whether the coloured cell-sap had any noticeable influence in controlling the temperature of leaves exposed directly to tropical sun. For, although little is known as to the temperatures which leaves in exposed positions, as tree-tops, reach-such an investigation being attended, as the writer found, by too great a personal equation on the part of the coolie employed in climbing the trees-it can hardly be doubted that at times the optimal temperatures for the various processes of the leaf may be exceeded.

It was argued that if the red colour of such leaves as Amherstia nobilis has a protective value in mitigating the temperature within the leaf the fact might be demonstrated by the thermometer.

The following experiment was made:

First, red and green leaflets of Amherstia nobilis (the green being thicker and tougher) were laid side by side on the grass in the bright sun, and thermometers were placed on either set. 
The thermometers resting on the rows of red and green leaflets respectively gave at intervals the following readings :

Thermometer resting on red leaflets $=32 \cdot 7^{\circ} \mathrm{C} .33 \cdot 4^{\circ} \mathrm{C} .34 \cdot 4^{\circ} \mathrm{C} .34 \cdot 6^{\circ} \mathrm{C} .34 \cdot 4^{\circ} \mathrm{C}$. , , $\quad$ green leaflets $=3 \mathrm{I} \cdot 9^{\circ} \mathrm{C} \cdot 32 \cdot 4^{\circ} \mathrm{C} \cdot 33 \cdot 2^{\circ} \mathrm{C} \cdot 33 \cdot 5^{\circ} \mathrm{C} \cdot 33 \cdot 3^{\circ} \mathrm{C}$.

Average temperature registered by thermometers :

$$
\begin{aligned}
& \text { On red leaflets }=33 \cdot 9^{\circ} \mathrm{C} \text {. } \\
& \text { On green leaflets }=32 \cdot 9^{\circ} \mathrm{C} \text {. }
\end{aligned}
$$

The thermometers were tested by transposing them, and showed their accuracy very distinctly thus :

Thermometer resting on red leaflets $=33 \cdot 7^{\circ} \mathrm{C} . \quad 34^{\circ} \quad 34 \cdot 2^{\circ} \mathrm{C} . \quad 33 \cdot \mathrm{I}^{\circ} \mathrm{C}$. $, \quad, \quad$ green leaflets $=33 \cdot \mathrm{I}^{\circ} \mathrm{C} . \quad 33 \cdot \mathrm{I}^{\circ} \mathrm{C} .33^{\circ} \quad 3^{2 \cdot 1^{\circ}} \mathrm{C}$.

Average temperature registered by thermometers :

On red leaflets $=33 \cdot 8^{\circ} \mathrm{C}$.

On green leaflets $=32 \cdot 8^{\circ} \mathrm{C}$.

In the second part of the experiment the thermometers were covered nearly up to the level of the mercury, one by the red, the other by the green leaflets.

The thermometers now gave the following readings :

Thermometer covered by red leaflets $=33 \cdot 5^{\circ} \mathrm{C} . \quad \begin{array}{lllllll}33 \cdot 3 & 3^{2} & 3^{\mathrm{I}} \cdot 6 & 3^{2} \cdot 3 & 33 \cdot 2 & 3^{2 \cdot \mathrm{I}}\end{array}$ $\begin{array}{lllllllll},, \quad & \text { green leaflets }=35^{\circ} \mathrm{C} . & 34 \cdot 4 & 3^{2 \cdot 9} & \mathbf{3}^{2 \cdot 3} & 34 & 34 \cdot 8 & 33 \cdot 3\end{array}$

Average temperature registered by the thermometers :

That covered by red leaflets $=32 \cdot 6^{\circ} \mathrm{C}$.

", , green leaflets $=33 \cdot 8^{\circ} \mathrm{C}$.

In short, when young thin red and older tougher green leaves of Amherstia are exposed side by side to the direct rays of the sun, the temperature, as registered by the thermometer, is higher to the extent of $1^{\circ} \mathrm{C}$. at the upper surface of the red leaves: conversely, of the temperatures registered at the lower surfaces of the leaves (i.e. behind them), that beneath the green is higher than that beneath the red, by a similar amount.

Put in general terms, the surface-layers of the red leaf reflect more heat than those of the green leaf. The green 
leaf, conversely, absorbs more of the sun's thermal rays than the red. Now, the two sets of leaves differ in two respects: first, in colour; then in that the green has a thicker, more developed cuticle (and mesophyll) than the red. This might, therefore, be expected to oppose a more solid resistance to the heat-rays than the thin immature cuticle of the red leaf. That such is not the case must be regarded as due to the fact that the different colouring-matters have different powers of reflection and absorption of heat, and that this difference is of such a nature that the red colouring-matter more effectually cuts off heat-rays from the body of the leaf than does the green. That is to say, the red colouring-matter acts as a screen by which the thermal effects of the sun's rays are moderated. That the red colouring-matters of leaves act powerfully in protecting the leaf from too intense action of light has been recently the subject of a research by Pick. This investigator finds that the photometric properties of the red colouring-matter enable it to protect the leaf, especially by cutting off rays which would interfere with the translocation of carbohydrates ${ }^{1}$.

In addition, then, to its value as a screen, the red or reddish coloured saps of such trees as Amherstia nobilis have the capability of affording to the young leaf, if necessary, a protection against too great heating effects of the rays of a tropical sun.

This colouration of the young foliage of trees of low latitudes is of very general occurrence. So general is it that a tropical forest presents at the time of its leaf-renewal an appearance which for beauty of tints rivals that which the trees of temperate climates exhibit in early autumn ${ }^{2}$.

It may be that these coloured saps, occurring often in trees whose leaves are, from their youngest stages, liable to a full

1 Pick, Bot. Centralblatt, B. XVI, Nos. 9-I 2.

${ }^{2}$ After writing the above I find the following remark in the paper by Johow to which reference has already been made, which shows that the prevalence of red saps in young foliage is not underestimated by me: 'All at once' (he is writing of the Lesser Antilles) ' a red tint, due to the young foliage of the trees, appears in the landscape.' Johow, loc. cit. p. 295. 
exposure to the sun, serve as the red sap of Amherstia nobilis seems to serve-not only as light-screens, but also as heatscreens, whereby the fierceness of the sun's rays is tempered to the young leaf; and although a difference of a degree-that recorded in the case of Amherstia nobilis-is not actually much, in times of danger it might mean the difference between life and death, or at all events between impaired or unimpaired functional activity and development.

In the group of trees under consideration this means of protection is not universal; and indeed it is only suggested that it seems to be a minor adaptation, which makes for the security of the young foliage whilst in its limp thin condition. That it does not occur in all by no means destroys this contention, since, to some trees, the production of coloured sap is a more simple task than to others. Thus it would seem to be simple to Amherstia nobilis, since the red colour not only characterizes the young foliage, but appears in the flower, the fruit, the buds and the flower-stalk.

In such trees as Humboldtia laurifolia, whose hanging foliage is white, it may be that greater thickness of cuticle is earlier arrived at, or that a slightly different habit or habitat renders such a minor adaptation of less importance.

Another factor, which in Amherstia nobilis may serve to reduce the temperature of the leaves, is their fugitive hairy covering. It is a curious point that these hairs, which render the young leaves of Amherstia nobilis very difficult to wet, disappear in the mature leaves; although, according to Stahl, it is those very mature leaves which need protection against wetting. That these mature leaves need some means whereby rainwater may be rapidly carried away from the leaf Stahl infers from their possession of a very long acuminate apices, to which in such and similar cases he has given the name of 'Träufelspitzen' (drip-tips). Stahl finds from experiment and observation on many species of plants that these acuminate apices are very useful in carrying away water which falls on the leaf ${ }^{1}$.

${ }^{1}$ Cf. also Junger's view, Bot. Centralblatt, 47 , No. I2, who suggests a similar function for these acuminate apices. 
Were this water not removed, transpiration and perhaps other functions of the leaf would, Stahl holds, be seriously checked.

Although, in experiments which I made, removal of the long apices from the leaves of Amherstia nobilis did not seem to impede the rapid drying of the leaf after rain, if it be allowed that some means of protection against prolonged wetting is needed, it might have been supposed, in the case of Amherstia nobilis, that such a protection would have been afforded in the mature leaf by the permanence of these hairs which, as stated, are present in the young. These, however, disappear. If Stahl's view of the value of these 'Träufelspitzen' be correct, then the hairs present in the young leaf have some other function, viz. protection against light or heat, and are superfluous as a means of protection against wetting.

As an alternative it may be suggested, with due deference to the distinguished author of 'Regenfall und Blattgestalt,' that these mature leaves of Amherstia nobilis have no especial need for a means of ' running off' of water from their surfaces. An observation of a detail may be mentioned here as shedding some light on the question of 'Träufelspitzen,' and also on the need for protection of the young leaves of Amherstia nobilis.

Three or four specimens of this tree grow, and grow well, in the Botanical Gardens at Perideniya. The longish apices (Träufelspitzen) of the mature leaves are almost without exception withered and dead. Now these apices consist of tissue which has not become so tough or coriaceous as the rest of the leaf. Nevertheless, whilst the leaves hang, the tips remain uninjured; when the leaves rise up and expose themselves to the sun these thin extremities are rapidly killed.

Whether the trees in the Perideniya gardens are growing under conditions similar to those which their ancestors in Tenasserim enjoyed is, of course, open to doubt; still the withering of the tips shows, and no more is urged here, that 
the tender leaves are at least safeguarded by their hanging position from damaging effects of sun.

Another noticeable fact with regard to these tips in Amherstia nobilis deserves notice. As the leaf passes from its red-brown stage to its full green condition, the tips, which were very long in the former stage, become, by growth of the leaf, less well marked. Now, in the young stage, they cannot, of course, function as 'Träufelspitzen,' since by the young leaf's position no rain falls directly on it, and also, so hairy are the young leaves that a continuous stream of water-drops splashed on them does not wet the surface-each drop rolling off at the nearest possible point. If the acuminate apex is a 'Träufelspitze,' why is the organ better developed at a time when it is useless-in the young stages, before it can be functional-than later, when the plant requires its aid?

In concluding this part of the subject, it may be mentioned here that the trees Amherstia nobilis, Brownea grandiceps, \&c., have not, in the formation of fresh shoots, the exact annual periodicity of most trees of temperate climates. So it happens in Ceylon that young branches arise all the year round, though in far greater numbers during the wet weather of the south-west monsoon. Now Potter points out ${ }^{1}$ that in those branches produced during the comparatively dry and hot weather, withering of the young pendent leaves not infrequently occurs. This withering certainly happens frequently in the young branches of the Amherstia nobilis trees which grow in the Botanical Gardens at Perideniya. On the view put forward by Potter, that this hanging habit is a direct adaptation to secure protection against the sun's action, this observation certainly shows the need for such protection.

The branches produced in the dry weather hang as long as, or even longer than, those produced during the rains, although, on Stahl's view, there is no reason why they should. If, then, his view be accepted it must be allowed that these trees have 
so thoroughly acquired the habit of hanging their foliage to avoid rain that they work independently of external conditions, and yet, at the same time, they have not acquired such periodicity as alone renders that habit of constant value.

When the events which occur during the period in which branch and leaf alike hang are examined, some light seems to be thrown on the significance of this habit.

About the time that leaves of Amherstia nobilis and Brownea grandiceps begin to take on their green colour, a periodic movement occurs in their leaflets. This movement, feeble at first, acquires a gradually increasing range. In these trees it is of such a nature that the leaflets move downwards during the sunny hours of the day, so that their surfaces make smaller angles with the vertical. This movement is continued during the night, so that in Amherstia nobilis the pairs of leaflets hang almost vertically downward. So general is this movement, being by no means confined to the young green leaves, that the tree at night has a most curious aspect, suggestive of the sleeping position assumed by many leaves. In the early morning, near sunrise, the leaflets stand well up approximately horizontally. Even in leaflets which show their maturity by their glossy, dark green colour, and their apparently rigid petioles, this diurnal movement occurs, though its range is decreased.

Practically the same movement occurs in the various species of Brownea; and, as an opportunity of raising seedlings of Brozenea grandiceps occurred, I was able to investigate this movement more fully in these.

As in the adult, so in a seedling Brownea bearing six or eight healthy leaves, the leaf-movement was similar to that already described. In early morning the leaves stood out more or less horizontally; but frequently, when the plants were growing in a room, the upward movement was continued for some hours after sunrise ; in later morning the downward movement began and continued into the night, giving place before daybreak to an upward movement. Thus in one case the angles, which a leaf of a seedling Brownea grandiceps 
made at different times of the day with the vertical, were observed. The measurement was made by affixing a short glass thread to the leaf, so that it projected about half an inch beyond and in a line with the midrib. This thread, whose point was blackened, played over the flat surface of a vertical semicircular arc of cardboard, whose radius was the distance between the point of insertion of the leaf and tip of the pointer, and which was graduated in degrees ${ }^{1}$.

Plant in room, diffuse light.

\begin{tabular}{|c|c|c|c|c|c|c|}
\hline At 10.50 & a.m. & Thursday & leaf & & above & izontal \\
\hline 2 & p.m. & , & ", & I $2.5^{\circ}$ & below & " \\
\hline $2 \cdot 30^{\circ}$ & ” & " & " & I $5^{\circ}$ & $"$ & \\
\hline 4 & ", & " & " & I $7.5^{\circ}$ & ", & $"$ \\
\hline 5 & $"$ & " & ," & $25^{\circ}$ & ," & " \\
\hline 6 & ," & ," & " & $30^{\circ}$ & ," & $"$ \\
\hline $8 \cdot 30$ & $"$ & & , & $3^{2} \cdot 5^{\circ}$ & , & , \\
\hline $6 \cdot 15$ & a.m. & Friday & ," & $10^{\circ}$ & ", & ," \\
\hline 8 & $"$ & , & $"$ & $7 \cdot 5^{\circ}$ & ", & \\
\hline${ }^{2} 10.40$ & ", & , & , & $4^{\circ}$ & " & ," \\
\hline II.IO & & ," & ," & $7 \cdot 5^{\circ}$ & ," & ," \\
\hline $2 \cdot 45$ & p.m. & ", & ," & $24^{\circ}$ & ", & ," \\
\hline 3 & ," & " & ", & $27^{\circ}$ & ," & , \\
\hline 3.55 & ," & ," & ", & $30^{\circ}$ & , & ," \\
\hline $6 \cdot$ I 5 & ", & " & " & $35^{\circ}$ & " & " \\
\hline $8 \cdot 30$ & & & ," & $40^{\circ}$ & ," & ," \\
\hline $6 \cdot 30$ & a.m. & Saturday & ", & $35^{\circ}$ & ", & " \\
\hline 8.25 & & , & $"$ & $45^{\circ}$ & ," & ", \\
\hline $4 \cdot 35$ & p.m. & " & , & $50^{\circ}$ & , & ", \\
\hline 3 & ", & , & , & $57 \cdot 5^{\circ}$ & ," & ", \\
\hline
\end{tabular}

These numbers show (I) that a leaf makes a larger angle with the horizontal, i.e. is more depressed, when exposed to direct sun than when in diffuse light; (2) that this is brought about, first, by the direct effect of sunlight on the periodic movement, and, secondly, by indirect after-effect, whereby the nocturnal recovery tends, in leaves which have been exposed to direct sunlight, to be inhibited. This latter indirect effect of sunlight explains the fact that young leaves of Brozenea grandiceps growing in the sun seem to hang permanently downward.

${ }^{1}$ See Darwin, Power of Movement, pp. 330, 331.

${ }^{2}$ At this point the plant was put in the open, but protected from rain and wind. The day was cloudy with but occasional sunshine. 
That bright sunlight brings about a depression was also shown in another way. Six seedling plants of Brownea grandiceps, at similar stages of development, were selected from a batch. Of these, two were placed in the open, fully exposed to the direct rays of the sun, the others were left in a room. When so placed there was nothing in the disposition of the leaves of the former to distinguish them from those of the plants which remained in the room. At the end of the first day of exposure it was found, as in the preceding case, that the leaves of the two plants in the open, made far larger angles with the horizontal-were much more depressed - than the leaves of those plants which were in the room. At the end of five days the difference between the two sets was most pronounced-all the leaves of the sun-exposed plants hung vertically down, whilst those of the plants in the room stood out more or less horizontally (cf. Fig. I with Fig. 2). Although the effect of exposure to the sun was so great, the daily periodicity of the movement was not destroyed; only the upward movement was greatly reduced. The same plant, when brought back into the diffuse light of the room, gradually recovered itself, so to speak, so that after several days the leaves raised themselves so as to stand horizontally, and once more performed their periodic movement in a way similar to that which obtained before exposure.

In the case of Amherstia nobilis it was not possible to directly measure the angles which the leaves made at various times with the vertical, although, as already stated, the general course of the movement can readily be followed without special arrangement. It was possible, however, by a rough method, not only to demonstrate the general course of movement of the leaflets of this plant during the day, but also to observe the relation that movement bears to the amount of insolation.

Fine beeswaxed threads were passed between opposite pairs of leaflets through holes in the basal parts of their laminae, close to the junction of lamina and petiole. The holes were large enough not to cause friction between the 
leaflets and thread, and thus not to impede any movement. A knot was made on one side of the thread, which was then gently tightened and an India-ink mark made where the thread passed through the opposite leaflet. By these means the distance between each pair of opposite leaflets, at the commencement of the experiment, was known. Any upward movement, whereby the leaflets approach a more horizontal position, was indicated by a greater length of thread becoming included between the leaflets, a downward movement by a bagging of the thread. The positions occupied by the leaflets, at different times of day and night, could then be compared.

Fourteen pinnate leaves, each two feet or more in length, and each bearing from three to seven threaded pairs of leaflets, were observed. The threads were passed through and marked between 7.30 and 9 o'clock on Monday.

The leaves chosen were mostly young, still more or less pendent, and brilliantly green ; some, however-and reference will later be made to these-had reached their mature fixed positions; and in these the petioles of the leaflets seemed to be quite rigid, although, as will be seen, they were still capable of some movement.

Allowing $(+)$ to stand for those leaflets which had become more horizontal (since in so doing they included more thread than between knot and India-ink mark); $(=)$ to denote those whose positions were unchanged; $(-)$ those which came to hang more vertically, the following numbers represent the results obtained :

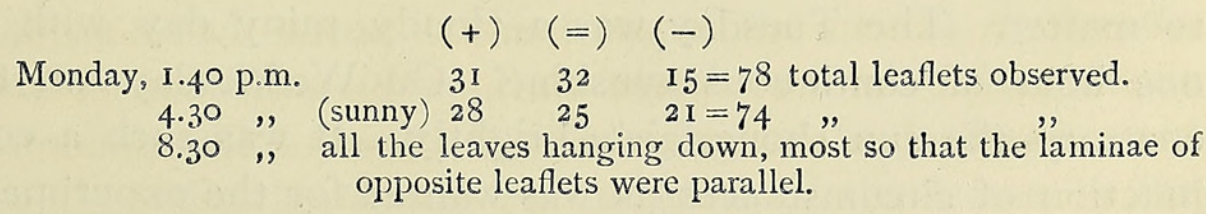$$
(+) \quad(=) \quad(-)
$$

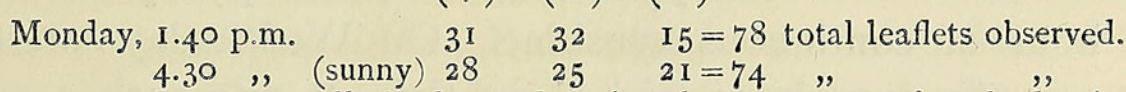$$
8.30 \text { " all the leaves hanging down, most so that the laminae of }
$$
opposite leaflets were parallel.

$(+) \quad \Leftrightarrow \quad(-)$

$43 \quad 23 \quad 7=73$


These numbers may be arranged in the form of a ratio, thus :

$$
\begin{gathered}
(-):(+) \\
\text { Monday, } 1.40 \text { p.m. I } 5: 3 \mathrm{I}=48: \text { I00 } \\
\text { ", } 4.30, " 2 \mathrm{I}: 28=75: \text { I00 } \\
\text { " } 8.30,, \quad \text { (most hanging downward, i. e. most }(-)) \text {. }
\end{gathered}
$$

Tuesday, $7 \cdot 30$ a.m. $7: 43=16 \cdot 3:$ Iо०.

When the roughness of the method is remembered, and also the difficulties attendant on even simple observations in the open, it will probably be conceded that the above statistics bear out what has already been described to be the movement possessed by leaflets of Amherstia nobilis. These observations were continued with a view to discovering if the amplitude of the movement in Amherstia nobilis was so markedly controlled by the amount of insolation as is the case in Brownea grandiceps.

The following results were obtained:

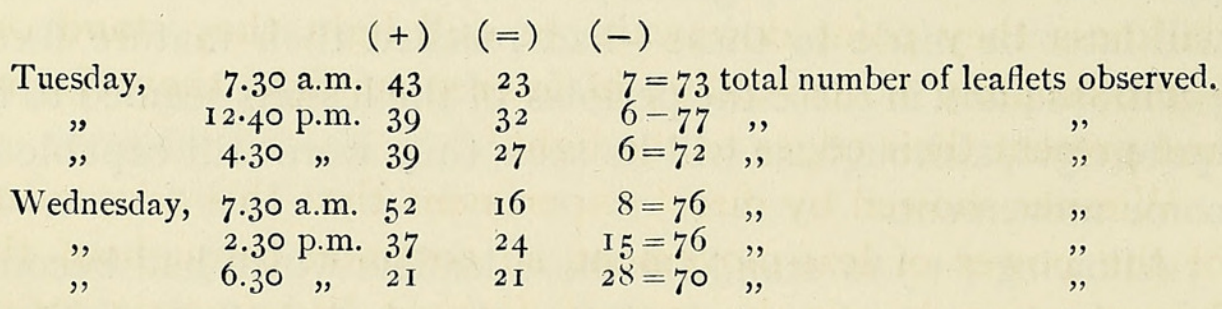

The discrepancies in the totals of the last column are due to the fact that it was sometimes impossible, owing to wind, \&c., to determine in a particular branch the positions of all the pairs of leaflets; but for the purpose for which the numbers are quoted these discrepancies are not sufficiently great to matter. The Tuesday was a cloudy, rainy day, with no one hour of continuous sunshine. On Wednesday, on the contrary, the sun shone fairly brightly. It was such a conjunction of circumstances as was wanted for the experiment. The results are noteworthy. On Tuesday, cloudy, no sun: at 4.30 p.m. only six pairs of leaflets were sufficiently depressed to make a difference in the length of thread between the pairs. On Wednesday, sun : at 2.30 p.m., i.e. two hours 
earlier, as many as fifteen pairs of leaflets were pendent, and at 6.30 twenty-eight pairs.

Here, then, it may confidently be asserted that, as in Brownea grandiceps, the position of the leaflets with respect to the vertical is daily determined by the amount of sunshine ; and that here also, as already demonstrated, in Brownea grandiceps, the amount of daily depression ultimately determines the plane taken up by the mature leaflet when, after weeks during which the extent of movement has been gradually waning, this leaflet assumes a fixed position.

The movement described, whereby the leaflets sink downward so as to expose their edges to the light, resembles in purpose that of Robinia Pseud-acacia; in this plant, however, the leaflets remain motile by virtue of their pulvini, whereas in Amherstia nobilis and species of Brownea the leaflets become ultimately fixed in a position of which the chief determinant is the amount of insolation received.

The movement of the leaflets of Robinia is such that during darkness they point downward, in dull light they stand out approximately horizontally; in intense sunlight they rise up and present their edges to the light ${ }^{1}$.

Wiesner showed by direct experiment that this adaptation of the power of leaf-movement, so common throughout the Leguminosae, has, in the case of Robinia Pseud-acacia, for its purpose the protection of the chlorophyll from too intense sunlight ${ }^{2}$.

The movements effected by the leaflets of Averrhoa bilimbi in response to bright sunlight have probably a similar significance; and these movements are of exactly the same nature as those which occur in the trees of the genera Amherstia, Brownea and Humboldtia. But Averrhoa bilimbi has a periodic movement which results in a hanging of the leaflets toward evening, and a horizontal outspreading of the leaves in the morning; whereas, as has been described, the leaflets of Brownea grandiceps, \&c., when growing in the diffuse light of

' Darwin, Power of Movement, pp. 355 and 445; and Wiesner, loc. cit., p. 27.

2 Wiesner, loc, cit. p. 26 et seq. 
a room, and therefore exposed to alternating conditions of darkness and of light of medium intensity, tend to assume a more or less horizontal position, from which they do not deviate nearly so much as when exposed directly to the sun : conversely, when growing in very sunny places the leaflets tend to be permanently depressed and to show a periodic movement of much less range than that which they possess when growing in places where the sun has less power.

If any inference may be drawn from the difference in the nature of the movements in Amherstia nobilis, \&c., on the one hand, and in Averrhoa bilimbi on the other, it would seem that, in the former, the movement is more especially adapted -if not solely-to protect the leaf from excessive insolation, in the latter, power of protection, not only from intense sun, but also from night exposure, exists.

Finally, Johow ${ }^{1}$ mentions that a protection against sunlight is effected in other of the Leguminosae, e.g. Pithecolobium trapezifolium, Acacia macrantha and Cassia spectabilis, by means of periodic movements.

The daily movement commences in the leaflets of Amherstia, whilst the branch and petioles are still in the pendent position, and indeed becomes very vigorous during this stage ; so much so that the leaflets, which have become green and stout, rise up under the combined influences of this movement and dia-heliotropism and place their leaves more or less horizontally-the extent to which they become thus outspread being, as already shown, determined by the amount of insolation they individually receive.

On Stahl's. view of the meaning of the hanging habit of the shoots, an obvious dilemma presents itself. The branch hangs downward for several weeks to enable the leaves to avoid rain; yet, whilst it thus hangs, the leaflets, which have, it is true, become tougher, rise up and expose themselves to rain. Thus a petiole bearing horizontally disposed leaflets continues for one or two weeks to hang vertically. If it be that the leaflets are become stout enough now to successfully 
withstand the shock of falling rain, why, it may fairly be asked, does the branch and leaf as a whole continue to hang so long after its function in so doing is fulfilled? If the leaves are not yet in a condition to withstand the shock of rain, the protective value of the hanging branch is rendered void by the exposed positions the leaflets now take up.

It has already been stated that the periodic movement continues, though with decreasing amplitude, in the leaflets whose petioles seem quite hardened and which are members of a leaf whose petiole has reached its mature uplifted position.

Thus the well-matured leaflets of a leaf which was in its final approximately horizontal position showed the following alterations in position :

\begin{tabular}{|c|c|c|c|c|}
\hline & & $(+)$ & $(=)$ & $(-)$ \\
\hline Saturday, & 5.30 p.m. & 4 & 2 & \\
\hline Sunday, & 9.30 a.m. & 4 & 2 & \\
\hline Monday, & $7 \quad$, & & 6 & \\
\hline , & I.40 p.m. & $(? 3)$ & 1 & 2 \\
\hline " & 4.30 & & 3 & 2 \\
\hline Tuesday, & 7.30 a.m. & & 6 & \\
\hline , & $\mathrm{I} 2.40 \mathrm{p} . \mathrm{m}$. & I & 5 & \\
\hline ", & 4.30 & I & 5 & \\
\hline Wednesday, & 7.30 a.m. & I & $4^{-5}$ & \\
\hline , & 2.30 p.m. & & 5 & I \\
\hline , & 6.30, & & 4 & 2 \\
\hline
\end{tabular}

This daily movement of the leaflets of Amherstia nobilis lasts, then, many weeks.

In yet a third tree (Humboldtia laurifolia), whose young branches and leaves hang, the ultimate positions assumed by the mature leaves are determined, as in Amherstia nobilis and Brownea grandiceps, by the extent to which they are exposed to the sun's rays.

One of these trees growing in the gardens is almost bushlike in habit. The bush is so dense that part is completely shaded. Branches of apparently the same age were cut from the external exposed and from the internal shaded parts, and the positions of the paired leaflets of the pinnate leaves estimated. This estimation was effected by placing each pair of leaflets in one of three groups, according as (I) the 
plane of the leaflet was vertical (downward), (2) the leaflet made an angle of about $45^{\circ}$ with the vertical, (3) the leaflet was disposed in a horizontal plane. The following are the results of thus enumerating the leaves of four branches of Humboldtia laurifolia:

$\begin{array}{lccc} & \text { Leaves } & \text { Leaves } & \text { Leaves } \\ & \text { (1) in vertical } & \text { (2) at } 45^{\circ} & \text { (3) in horizontal } \\ \text { plane. } & 8 & & \text { plane. } \\ \text { Shade branches } & 27 & 2 \text { I } & \text { I9 } \\ \text { Sun branches } & 27 & 20 & 0\end{array}$

there being an average of four pairs of leaflets to each pinnate leaf, the total number of leaflets in the various positions is:-

\begin{tabular}{|c|c|c|c|c|}
\hline & $\begin{array}{l}\text { Leaflets } \\
\text { (I) parallel with } \\
\text { vertical. }\end{array}$ & $\begin{array}{l}\text { Leaflets } \\
\text { (2) } 45^{\circ} \text { with } \\
\text { vertical. }\end{array}$ & $\begin{array}{c}\text { Leaflets } \\
\text { (3) in horizontal } \\
\text { plane. }\end{array}$ & $\begin{array}{l}\text { Total } \\
\text { leaves. }\end{array}$ \\
\hline & 64 & I 68 & 152 & $=384$ \\
\hline an branches & 216 & I60 & 0 & $=37^{6}$ \\
\hline
\end{tabular}

or expressed in percentages:

$\begin{array}{lccc} & \text { Leaflets } \\ \text { (I) } & (2) & (3) \\ \text { Shade branches } \% \text { 16.6 } & 43 \cdot 7 & 39 \cdot 6=99 \cdot 9 \\ \text { Sun branches } \% 57 \cdot 4 & 42 \cdot 5 & =99 \cdot 9\end{array}$

Hence therefore, what happens in Amherstia nobilis and in Brownea grandiceps also occurs in Humboldtia laurifolia, viz. the mature position of each leaflet is determined by the amount of insolation to which it is exposed: that in all these trees this position is arrived at by the amplitude of the daily variation of the periodic movement being influenced by the amount of light which falls upon the leaves. Intense insolation causes great depression of the leaflets, and this depression is not fully compensated by the uprising which occurs normally during the night. Thus it comes about that leaflets exposed, for example, for many days to a bright sun assume more and more a position in which the apex points downward, and as the inherent power of periodic movement wanes the leaflet becomes fixed in this position. If, on the other hand, the leaflet is produced in dense shade the periodic 
movement enables it to rise up daily to a fully horizontal position; and, in the absence of the sun's direct influence, after performing its daily swing, the final plane of the leaflet is horizontal. Thus the shaded leaflet makes the most of its leaf-surface, the sun-exposed leaflet adjusts itself doubtless in that position in respect to the sun in which the various functions of the leaf are best fulfilled; in which transpiration is not too excessive, and quite probably also in which assimilation and translocation in the leaflet are most favourably affected by the sun's light- and heat-rays. For Costerus ${ }^{1}$ has quite recently shown, or at least gone far towards showing, that leaves of trees are markedly influenced by the sun's rays, in the rate of their assimilation and translocation. In connexion with the ultimate position assumed by the leaves of Brownea grandiceps, another factor which may make itself felt is the directive influence of light, for, like other dorsi-ventral leaves, those of this tree are dia-heliotropic. Thus three or four seedlings, which had been grown in the diffuse light and whose leaflets were horizontally disposed, were so placed in a room as to be unilaterally illuminated. At the end of fourteen days the leaflets had all arranged their upper surfaces at right angles to the light. To do this not a few had been compelled to rise up so that their apices pointed upwards to such an extent that the plane of the leaf made but a very small angle with the vertical.

The effect of this dia-heliotropism is often well marked in leaves of Brownea grandiceps trees growing in shady places. In such cases not only do the petioles of the most shaded pinnate leaves rise up more than those exposed to the light, but the leaflets themselves assume positions quite like those taken up by the leaves of such plants as Veronica Traversi, Lamium album ${ }^{2}$, \&c., viz. each pair of leaflets lies in one plane at right angles to the incident light.

Consider now to what conditions of insolation these trees of the genera Amherstia, Brownea, and Humboldtia, whose leaves

1 Costerus, Ann. Jard. Buitenzorg, XII. I.

${ }^{2}$ Cf. Physiology of Plants, Darwin and Acton, Fig. 23. 
possess means of such accurate adjustment to light, are naturally exposed.

It is noteworthy that this phenomenon of hanging branches occurs in small trees. Brownea grandiceps, Brownea coccinea, and another species, Brownea hybrida, grow well in the gardens. The tallest of these is less than forty feet in height; the others are much less. The genus Brownea is described in the Treasury of Botany ${ }^{1}$ as ' a genus of small evergreen trees.... peculiar to Venezuela, New Granada. ...' Humboldtia laurifolia, often more a shrub than a tree, is thus described by Trimen: 'A small tree or shrub with numerous horizontally-spreading or rather drooping branches'.' Cynometra ramiflora is stated by the same authority to be 'a small, moderately sized, much branched tree ${ }^{3}$.'

Saraca (Fonesia) indica, 'rather small, much branched, spreading tree ${ }^{4}$; and of the genus Fonesia the Treasury of Botany says, "They are large shrubs or trees of twenty to forty feet in height ${ }^{5}$ '. Kurz, in his Flora of British Burmah, gives the height of Amherstia nobilis as forty feet ${ }^{6}$.

The only apparent exception seems to be Calophyllum bracteatum, a tree peculiar to Ceylon, and rare. Of it Trimen writes 'a large tree ${ }^{7}$.' I did not see a specimen of this treea member of the order Guttiferae. Much interest attaches to it in belonging to so widely separated an order from that (Caesalpinieae) to which most if not all other trees with hanging foliage belong. Whether this species grows to the height reached by other members of the genus, 80 to 100 feet, cannot be stated. At present it must be looked upon as an exception to the otherwise general rule, that the trees whose young branches and leaves hang down are small and spreading.

1 Treasury of Botany, Vol. I, p. I73.

${ }^{2}$ Dr. H. Trimen, Handbook to the Flora of Ceylon, pp. 2, I I 5.

3 Ibid., Part I, p. IO2.

4 Ibid., Part II, pp. I I I, I I 2.

5 Loc. cit., Part I, p. 633.

${ }^{6}$ Kurz, Forest Flora of British Burmah, Vol. i, p. 4 I I.

${ }^{7}$ Loc. cit., Part I, p. IO2. 
This spreading habit is markedly characteristic of Brownea grandiceps, Brownea coccinea and other species, of Saraca indica, Cynometra ramiflora, and of Humboldtia laurifolia. The low spreading habit is due to, or at all events is associated with, the fact that these trees, with possibly one exception, are shade-loving. According to Kurz both Amherstia nobilis and Saraca indica are shade-loving trees ${ }^{1}$. I have been assured that the species of Brownea common to Venezuela grow deep in the jungles, in which case these too (see later) must be shade-loving plants. Trimen ${ }^{2}$ gives the following characters which point toward similar conclusions in other cases: thus Calophyllum bracteatum, 'moist, low country in wet forests :' Humboldtia laurifolia, 'damp places in forests, moist, low country.'

The doubtful case is Cynometra ramiflora, which, according to Kurz, is a light-loving tree, though Trimen gives its habitat as forests of low country in dry regions. The latter authority informs me that it is more than probable that two species are confounded in Cynometra ramiflora, so that the tree with hanging foliage may after all be only an apparent exception to the general rule that these trees are shade-lovers.

All the trees above enumerated, with one possible exception already noted, are small much-spreading and branching foresttrees, which show a marked preference for the shade.

Now, of all trees growing in forests, those which seek such sheltered positions-which grow under the shadow of loftier trees, whose branches, together with the many climbers thereon, make, in a tropical jungle, such a tangled mass of vegetation-are the very last to require special protection against the force of falling rain. Fall the tropic rain never so heavily, its force is spent, broken by the roofing masses of foliage, before it arrives at this arboreal undergrowth. Hence Stahl's view that the hanging branches are an adaptation against the damaging, rupturing effects of heavy rain, cannot, if acceptance be given to the above arguments and observations, be main-

${ }^{1}$ Loc. cit., Vol. i, pp. 4I I , 4I 5.

${ }^{2}$ Loc. cit. 
tained. Whether tropical rain is in general so inimical to young foliage as Stahl believes is a question which experience rather than experiment will finally decide.

It may be mentioned that seedlings of Brownea grandiceps, whose tender leaves happened to be arranged horizontally, were exposed to heavy showers without sustaining any apparent injury, though to this may naturally, and perhaps truly, be objected that heavier rains would have destroyed them.

Yet, within my very limited experience of the tropics, it is mainly the withered leaves, the decayed branches, which strew the ground after heavy tropical rain.

Stahl's observations ${ }^{1}$, however, have the merit of being positive, and record great destruction after rain: 'thousands of flowers, old and young foliage, even whole branches, strew the ground after heavy torrents of rain.'

Even admitting, however, that the damage done to, or risk incurred by, young foliage in general, is as great as Stahl describes, it in no way impairs the conclusion above arrived at, that the hanging habit in these shade-loving trees is not a special provision against this damage or risk.

As stated above, the 'shade-loving' habit of Brownea grandiceps was examined with some care. This was rendered easy by the fact that several trees, apparently not differing greatly in age, were growing in the gardens. Of these trees one grows in a particularly shaded place, hedged in by larger trees; another grows exposed on all sides to the sun.

Now Wiesner has described the changes in appearance which 'shade-loving' shrubs undergo when grown in sunny places 2 . 'When growing in the shade the shrub exposes its young leaves, in which chlorophyll is developing, to the light; the young branches are long in comparison with those growing in direct light ; the young leaves do not, during development, place themselves in the shade of the older, and generally show no deviation from their normal position in relation to the stem. When such a shrub is grown in light, the 
stem-members shorten, and consequently the leaves are closer together; the youngest leaves shade themselves under the older; the young leaves stand generally approximately upright in the direction of the axis bearing them, and thus make but small angles with the most powerful sun's rays.'

As far as I am aware, similar divergences called forth by differences in insolation have not been described in trees; yet Brownea grandiceps shows an agreement with those divergences too obvious to be accidental.

In the shade-growing tree the leaves and leaflets soon become horizontally disposed; the main branches make wide angles with the main trunk, which divides within a foot or so of the ground into several branches. These main branches, spreading horizontally, give rise to lateral members, which also make but small upward angles-some running out away from the centre of the tree, others toward it. Hence the tree assumes a sort of ' umbrella' outline. The tree growing in the sun is, on the contrary, pyramidal (applying the word in the sense in which it is used in describing the shapes of such trees as the Poplar); its main branches rise up steeply, and its leaves have a much more marked vertically downward tendency. The branches of the shade-growing tree are longer than those of a tree growing exposed to the sun; and consequently the former has a more spreading habit. When it is remembered that Brownea grandiceps is a tree, albeit a small one, the apparent paradox propounds itselfa tree, by its nature a seeker after light, loves the shade. Does it, then, seem unreasonable to suppose that such plants, whose constitution is so unadapted to withstand great light, should not only have the means, by virtue of the power of movement of their leaves, to protect, if need be, their old blades from an excessive sun, but also have special means of protection for young leaves.

Since the course of the foregoing argument is at times interrupted by descriptions of experiments, I wish here to briefly sum up-to point out how far previous views are supported by these experiments, how far they seem to me 
to be rendered doubtful; and, in conclusion, to put forward a somewhat more extended view of the significance of this hanging habit. From the observations of the destruction of chlorophyll, of the rates of transpiration, of the shadeloving habits of the trees, it cannot, I think, be doubted that the young leaves are protected by their hanging position. But in addition to this temporary advantage I would suggest an additional permanent advantage-permanent in the sense that its benefit is felt throughout the life of the branch. Beside affording protection to the young foliage, by this habit the branch and its pendent petioles are able to wait in a safe position till the conditions of shade or sun, as far as they are determined by the disposition of the young branches of other shoots, can, to use a figure of speech, be ascertained. At all events, during this delay, a step toward the permanent condition of light or shade is being made by the adjustment of other shoots; so that, on rising up, the branch with its leaves meets conditions more akin to those under which it must live than if it had pushed its way horizontally. But still more important is the fact that the pinnate leaves have a far greater range of positions which they can adopt than if they had grown in the normal way, obliquely outward, their basal parts becoming rapidly rigid, so that only their growing apical parts could adjust themselves to changing conditions of insolation. The petiole has, on rising, the power of assuming any position, from one pointing almost vertically downward to one pointing upward. Such a power of responding to differences of external conditions could not exist in a petiole which arose at a certain definite angle with the stem, and whose basal part became rapidly rigid.

By means of the 'waiting' and the rising up of the branch and the petiole, the shoot may be likened in its behaviour to one of the leaflets borne by the petiole: both adjust themselves to a nicety to the prevailing conditions of insolation.

To state the case in another way: the two movements of the shoot with its leaf and of the leaflets may be likened 
to a coarse and fine adjustment-to use a comparison suggested to me by Mr. Francis Darwin. The coarse adjustment is effected by the rising up of the petiole, the fine adjustment by the periodic movement of the leaflets. These latter also have the power of temporary adjustment from day to day before and during the uprising of the petiole.

During the hanging of the leaf, when the permanent conditions to which the branch will be exposed are being arrived at, the power of the leaf to assume any position within a range of nearly $180^{\circ}$ is possible; and this enables every leaflet of the tree to arrive at its best possible position with respect to insolation.

In addition, then, to the protective value suggested by previous writers, which has been demonstrated in the foregoing paper, I would suggest that the habit under examination has an additional value of adjustment; whereby a greater 'choice' of positions is at the disposal of branch and leaf.

Although hunting for teleological explanations may not in itself be a productive task, yet, in so far as these 'explanations' open up new points of view, they are, I venture to submit, the just objects of biological research: thus I would justify the line of argument employed in this paper.

In conclusion, I wish to acknowledge the great kindness shown to me by the Director of the Royal Botanical Gardens of Ceylon, Dr. Trimen, who granted me permission to make use of the gardens and of the laboratory. I also beg to express my thanks to Mr. Francis Darwin, who has aided me in the writing of this paper with much valuable criticism. 
94 Keeble.-Hanging Foliage of Tropical Trees.

\section{EXPLANATION OF FIGURES IN PLATE IV.}

Illustrating Mr. Keeble's paper on the Hanging Foliage of certain Tropical Trees.

Fig. I. a. Seedling Brownea grandiceps grown in diffuse light of a room.

,b. Pair of leaflets of the same for comparison with Fig. $2 b$.

Fig. 2. a. Seedling Brownea grandiceps grown for three days in sun; cf. Fig. 1 a.

, $\quad b$. Pair of leaflets of the same.

Fig. 3 (after Haberlandt, Eine botanische Tropenreise, p. II8). A young hanging shoot of Amherstia nobilis. 
Annals of Botany

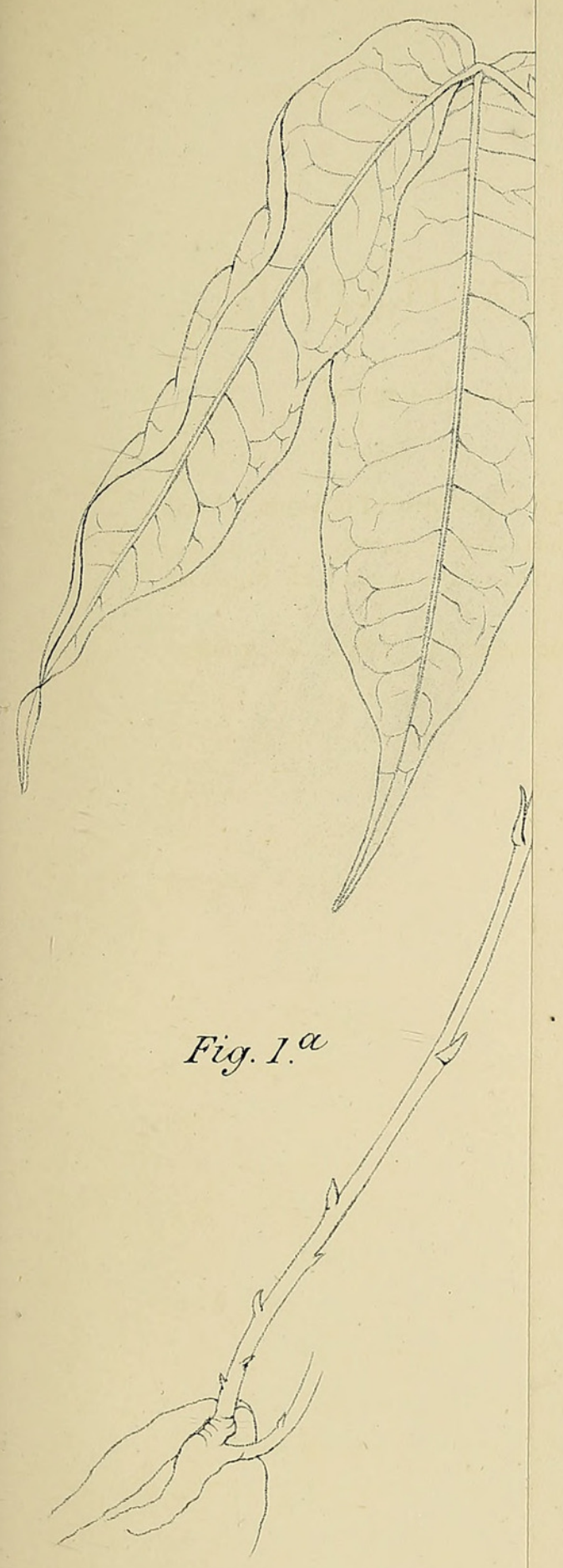

Fig. 3. 
Annals of Botany

Vol. IX, PL.IV.

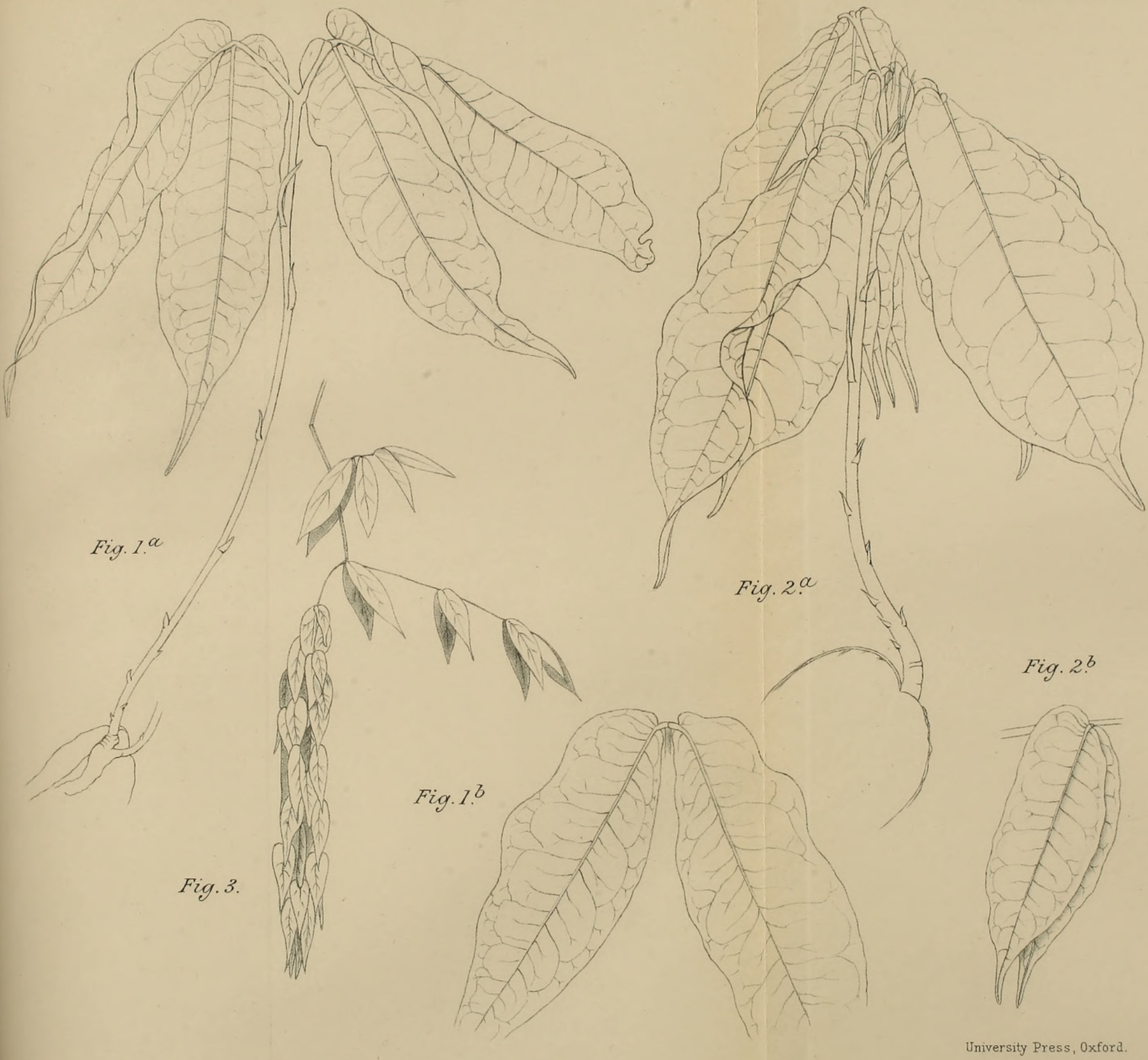

KEBLE. - HANGING FOLIAGE. 


\section{$2 \mathrm{BHL}$ Biodiversity Heritage Library}

Keeble, Frederick. 1895. "The hanging foliage of certain tropical trees." Annals of botany 9, 59-94. https://doi.org/10.1093/oxfordjournals.aob.a090734.

View This Item Online: https://www.biodiversitylibrary.org/item/233478

DOI: https://doi.org/10.1093/oxfordjournals.aob.a090734

Permalink: https://www.biodiversitylibrary.org/partpdf/318366

\section{Holding Institution}

Smithsonian Libraries

\section{Sponsored by}

Biodiversity Heritage Library

\section{Copyright \& Reuse}

Copyright Status: Not in copyright. The BHL knows of no copyright restrictions on this item.

This document was created from content at the Biodiversity Heritage Library, the world's largest open access digital library for biodiversity literature and archives. Visit BHL at https://www.biodiversitylibrary.org. 